\title{
Spectral Composition of Sunlight Affects the Microbial Functional Structure of Beech Leaf Litter During the Initial Phase of Decomposition
}

\author{
Marta Pieristè (D) - Estelle Forey • Anissa Lounès-Hadj Sahraoui • Hacène Meglouli • \\ Frédéric Laruelle • Philippe Delporte • T. Matthew Robson • Matthieu Chauvat
}

Received: 28 October 2019 / Accepted: 30 April 2020/Published online: 15 May 2020

(C) The Author(s) 2020

\begin{abstract}
Aims This study tests whether different spectral regions of sunlight affect the microbial decomposer assemblage in surface leaf litter in a beech understorey over the first 6 months following leaf senescence.

Methods We performed a litterbag experiment employing filters attenuating combinations of UV-B, UV-A, blue, and green light as well as the whole spectrum of sunlight. We measured changes in microbial biomass and community structure, litter mass loss and litter chemistry during the first 6 months of decomposition.
\end{abstract}

T Matthew Robson and Matthieu Chauvat Joint last author contribution

Responsible Editor: Feike A. Dijkstra .

Electronic supplementary material The online version of this article (https://doi.org/10.1007/s11104-020-04557-6) contains supplementary material, which is available to authorized users.

M. Pieristè $(\bowtie) \cdot$ T. M. Robson

Organismal and Evolutionary Biology (OEB), Viikki Plant

Science Centre (ViPS), University of Helsinki, P.O. Box 65

(Viikinkaari1), 00014 Helsinki, Finland

e-mail: marta.pieriste@helsinki.fi

M. Pieristè $\cdot$ E. Forey $\cdot$ P. Delporte $\cdot$ M. Chauvat UNIROUEN, IRSTEA, ECODIV, Normandie Université, FR

Scale CNRS 3730, Rouen, France

A. Lounès-Hadj Sahraoui · H. Meglouli · F. Laruelle Unité de Chimie Environnementale et Interactions sur le Vivant (UCEIV), EA 4492, Université du Littoral Côte d'Opale, SFR Condorcet FR CNRS 3417, 50 rue Ferdinand Buisson, 62228 Calais, France
Results Fungal and total microbial biomass were highest in the treatment excluding UV radiation, blue and green light. Exclusion of UV-B radiation decreased the fungal:bacterial biomass ratio and litter nitrogen content. Bacterial biomass was lower in the dark treatment compared to treatments receiving at least part of the solar spectrum. Our filter treatments affected microbial functional structure from the beginning of the experiment, whereas mass loss was only significantly affected after 6 months of decomposition and no effect was found on litter carbon content.

Conclusions This study proves that sunlight, in a spectrally dependent manner, affects both microbial functional structure and biomass in temperate deciduous forests early in the decomposition process, with bacteria tending to dominate in sunlight and fungi in dark conditions. We found sunlight to be important in the decomposition in temperate forest understoreys despite the low irradiance characterizing these environments. However, long-term studies are required to estimate the relative contribution of sunlight among factors affecting the eventual incorporation of decomposing leaf litter into forest soils.

Keywords Photodegradation · UV · Blue light · Green light $\cdot$ Microbial communities $\cdot$ PLFA

$\begin{array}{ll}\text { Abbreviations } & \\ \text { AFDM } & \text { Ash-Free Dry Mass } \\ \text { AMF } & \text { Arbuscular Mycorrhizal Fungi } \\ {[\mathrm{C}]} & \text { Carbon content } \\ \mathrm{C}: \mathrm{N} & \text { carbon-to-nitrogen ratio }\end{array}$




$\begin{array}{ll}\text { F:B } & \text { fungal-to-bacterial biomass ratio } \\ \text { FAMEs } & \text { Fatty-Acid Methyl Esters } \\ \text { DW } & \text { Dry Weight } \\ \text { GLI } & \text { Global Light Index } \\ \text { Gram-N } & \text { Gram-negative bacteria } \\ \text { Gram-P } & \text { Gram-positive bacteria } \\ \text { Gram-P:Gram-N } & \text { Gram-P bacteria to Gram-N } \\ & \text { bacteria biomass ratio } \\ \text { LAI } & \text { Leaf Area Index } \\ \text { [N] } & \text { Nitrogen content } \\ \text { NLFA } & \text { Neutral Lipid Fatty Acids } \\ \text { PAR } & \text { Photosynthetically Active } \\ & \text { Radiation } \\ \text { PLFA } & \text { Phospholipid Fatty Acid } \\ \text { UV } & \text { Ultraviolet radiation }\end{array}$

\section{Introduction}

In most terrestrial ecosystems, sunlight is prominent among the suite of biotic and abiotic factors driving the litter decomposition process. This is true for arid (Day et al. 2015; Day et al. 2007) to mesic (Brandt et al. 2010) ecosystems, grasslands (Almagro et al. 2017; Brandt et al. 2007) to woodlands (Pieristè et al. 2019a; Pieristè et al. 2019b), and low (Ma et al. 2017) to high latitudes (Pancotto et al. 2003). The mechanism through which sunlight interacts with litter decomposition is known as photodegradation (Bais et al. 2018), and it is driven by UV-B (280-315 nm) and UV-A (315$400 \mathrm{~nm}$ ) radiation and the short-wavelength regions of visible light (blue 420-490 nm and green 500-570 nm) (Austin et al. 2016). Photodegradation encompasses different processes, i.e. direct (photomineralization, photoinhibition) and indirect (photofacilitation, also known as photopriming) (King et al. 2012), interacting with the other biotic and abiotic drivers of decomposition. As a consequence, sunlight can increase (Day et al. 2007) or decrease (Pancotto et al. 2003) the decomposition rate and potentially affect nutrient cycling (Foereid et al. 2011). The question of whether direct or indirect and positive or negative effects dominate, depends on the climate and the type of ecosystem considered (Almagro et al. 2017). For instance, in mesic environments, where microbial decomposition is the predominant process, direct photoinhibition appears more important than direct photomineralization; which plays a greater role in arid environments at lower latitudes were UV radiation is higher (Bais et al. 2018).

At present, two contrasting effects of sunlight on microbial decomposition are known: photofacilitation and photoinhibition. The first involves the facilitation of microbial decomposition as a result of direct photomineralization of litter typically increasing its bioavailability (Baker and Allison 2015, but see Austin et al. 2016 for a counter-example), while the second refers to direct inhibition of microbial decomposition by sunlight, reducing respiration and altering the structure of microbial assemblages (Duguay and Klironomos 2000; Verhoef et al. 2000). Both these processes are thought to be dependent on the spectral composition of sunlight to which litter and decomposers are exposed (Lin et al. 2018), and thereby may occur concomitantly. For instance, Austin et al. (2016) found that microbial decomposition was inhibited as a consequence of preexposure of litter to UV radiation, while photofacilitation occurred when litter was exposed to blue and green light. Furthermore, the relative importance of photofacilitation and photoinhibition seems to depend on the duration of exposure (King et al. 2012; Lin et al. 2018). Most studies into the effect of sunlight on microbial decomposition and decomposer communities focus on UV radiation, more specifically the UV$\mathrm{B}$ region: often trying to simulate potential effects of ozone depletion in arid environments, consequently applying very high UV-B doses, which are not necessarily interpretable for most environments receiving ambient sunlight (Duguay and Klironomos 2000; Lin et al. 2018; Moody et al. 1999). High UV doses such as these can reduce spore germination and fungal hyphal length in fungi colonizing leaf litter (Moody et al. 1999; Verhoef et al. 2000), but evidence is lacking on whether these effects also occur under ambient UV doses.

Only a few recent studies in arid and semiarid environments have analysed photofacilitation and photoinhibition processes in natural conditions (Baker and Allison 2015; Ball et al. 2019; Day et al. 2018; Pancotto et al. 2003). Exposure to ambient UV radiation and blue light enhanced microbial respiration in an arid environment (Day et al. 2018), while bacterial biomass seemed to be reduced (Ball et al. 2019), suggesting a higher metabolic quotient (Anderson and Domsch 1990, 1993). The opposite effect was found in a Mediterranean climate, where microbial respiration was reduced by exposure of Bromus diandrus litter to UV radiation (Lin et al. 2015). These contrasting results from different 
ecosystems make it hard to generalize about the effects of UV radiation on litter decomposer organisms. Moreover, to be able to scale photodegradation effects across ecosystems and biomes, it would be necessary to separate the direct and indirect effects of sunlight on litter and decomposer organisms in ecological studies.

Those arid and semiarid ecosystems are characterized by low canopy cover, while there are only a few studies under forest canopies (Newsham et al. 2001; Pieristè et al. 2019a; Pieristè et al. 2019b). Deciduous forest understoreys are very-dynamic light environments, in which irradiance and its spectral composition vary over the year as the canopy flushes in spring and opens in autumn (Hartikainen et al. 2018). Although irradiance can be low in the understorey, sunlight can enhance the decomposition of leaf litter in temperate forests and the effect is dependent on initial litter quality, as found for three tree species of differing litter quality in a beech forest in France (Pieristè et al. 2019a). However, this effect seems to vary according to the canopy species and latitude: whereby irradiance interacts with different environmental conditions in winter at high- and midlatitudes (Pieristè et al. 2019a; Pieristè et al. 2019b). Moreover, during autumn and winter, when the canopy is dormant in deciduous forests, the direct exposure of litter to sunlight has the potential to enhance mass loss and, as a consequence, we could expect to see a priming effect that would facilitate subsequent microbial decomposition (photofacilitation) at later stages (Hättenschwiler et al. 2005; Swift et al. 1979), similar to the processes observed in arid environments.

In forest environments, microbial decomposition drives nutrient cycling and determines nutrient availability to plants (Asplund et al. 2018). Saprophytic and ectomycorrhizal fungi play a decisive role in litter decomposition in these ecosystems and are considered as primary decomposers, due to their capacity to break-down recalcitrant components of leaf litter inaccessible to other organisms (Baldrian 2016; Kubartová et al. 2009). Fungal decomposers colonize litter in the early stages of decomposition, while bacteria appear relatively late and take advantage of the fragmentation of litter and nutrients released by fungi and invertebrates during the initial phase of decomposition (Purahong et al. 2014). Recently, however, several studies have suggested that many bacterial taxa are better adapted to decompose complex C-compounds than previously thought (Sauvadet et al. 2019).
Enhanced UV, and its constituent UV-B, radiation reportedly reduce spore germination and fungal hyphal length in fungi colonizing leaf litter (Moody et al. 1999; Verhoef et al. 2000). On the other hand, UV-A radiation has been found to enhance sporulation in some fungal phytopathogens (Paul and Gwynn-Jones 2003), but inhibit sporulation and delay germination of the conidia of some saprophytic fungi (García-Cela et al. 2016; Osman et al. 1989). However, this effect seems to depend on the dose of UV-A radiation, the length of the exposure, the interaction with UV-B radiation and the fungal species considered (Fourtouni et al. 1998; Kumagai 1988; Osman et al. 1989; Paul and Gwynn-Jones 2003). In the same way, the photosensitivity of bacteria is species specific and depends on traits such as pigmentation (Paul and Gwynn-Jones 2003). Since microbes have a crucial role in carbon and nutrient cycles in forest ecosystems (Johnson 2003), it is important to know how they respond to UV radiation and visible light, to better understand the potential effects of changes in spectral composition due to changing canopy phenology.

This study aims to test whether sunlight has an impact on the initial phase of microbial decomposition in the understorey of a temperate forest, and to distinguish the effects that different regions of the solar spectrum can have on microbial decomposition. Hence, we performed a 6months litterbag experiment employing filters over Fagus sylvatica litter to successively attenuate more of the shortwavelength spectral regions of solar radiation from UV-B to green light (Table S1; Fig. S1). We determined mass loss, carbon content $[\mathrm{C}]$, nitrogen content $[\mathrm{N}]$ and microbial biomass and community structure through PLFA analysis. We expected the attenuation of different spectral regions to lead to dissimilar microbial assemblages with different decomposition rates compared to full sunlight exposure. In particular, we expected treatments excluding UV radiation and blue light to have the highest fungal and bacterial biomass due to removal of the inhibitory effect of these spectral regions, producing a higher photodegradation rate. We expected litter exposed to the full spectrum of sunlight to have higher mass loss and [C] loss than the other treatments due to the presence of shortwave radiation (UV radiation and blue and green light) promoting photomineralization and photofacilitation. Moreover, we expected the dark treatment to have the lowest decomposition rate due to the absence of photodegradation. 


\section{Material and Methods}

\section{Site Description}

The experiment was conducted in a mature pure beech forest (Fagus sylvatica L.) in Forêt Verte (49³1'12.6"N $\left.1^{\circ} 07^{\prime} 00.7^{\prime \prime} \mathrm{E}\right)$, close to Rouen University, France. The topography at the site is flat and the elevation is about $150 \mathrm{~m}$ a.s.l. The understorey at the site of deployment of the litterbags was absent and removed where present (see Fig. S5). The climate of the field site is oceanic temperate, the mean annual air temperature is $10.5^{\circ} \mathrm{C}$ and the total annual precipitation average $851.7 \mathrm{~mm}$, distributed relatively evenly over the year. During the study period, the average temperature in the understorey was $8.7^{\circ} \mathrm{C}$ (see Fig. S4 for more details). At the end of the 6 months of the study the understorey received about $1160 \mathrm{~mol} \mathrm{~m}^{-2}$ of PAR and about $90 \mathrm{~mol} \mathrm{~m}^{-2}$ of UV (see Table S1 for details about light doses).

Spectral irradiance of sunlight was measured outdoors, inside the litterbags for each filter treatment and without any filter in the forest understorey (Fig. S1). Measurements were taken using an array spectroradiometer (Maya2000 Pro Ocean Optics, Dunedin, FL, USA; D7-H-SMA cosine diffuser, Bentham Instruments Ltd., Reading, UK) that had been calibrated within the previous 12 months for highest precision over the regions of solar UV radiation and photosynthetically active radiation (PAR) (see Hartikainen et al. (2018) for details of the calibration, Aphalo et al. (2012), Aphalo et al. (2016)). Hemispherical photos were taken on multiple occasions to capture the different stages of canopy development. These photos were used to characterize canopy cover by calculation of the global light index (GLI) and the leaf area index (LAI) with the software Hemispher (Schleppi et al. 2007, Thimonier et al. 2010). The LAI was estimated to be $0.74 \pm 0.06$ during winter (Dec 2017 - mid Apr 2018) corresponding to a GLI of $41.69 \% \pm 1.00 \%$. On 14th May 2018, when canopy leaves were completely expanded, the LAI reached $2.96 \pm 0.40$ while the GLI dropped to $11.62 \% \pm 3.05 \%$. Above-canopy irradiance data were obtained from SoDa Helioclim-3 (Blanc et al. 2011; Gschwind et al. 2006; Udo and Aro 1999). Modelled understorey irradiance data were calculated by applying the GLI to the above-canopy irradiance data (Canham 1988) following the protocol from Pieristè et al. (2019b) and Hartikainen et al. (2018). Estimates of received PAR, UV-A and UV-B radiation are given (Fig. S2,
Fig. S3, Table S1) according to the spectral composition of modelled incident solar radiation; adjusting for the relative enrichment of UV radiation in shade (Hartikainen et al. 2018) by comparison with the understorey spectral irradiance measured as described above.

Temperature inside a representative sub-sample of litterbags was continuously monitored with ECH2O 5TM sensors (Decagon devices, Pullman, Washington, USA). These data showed no significant differences in temperature between litterbags from the six different filter treatments ( $p=0.814$, ESM Fig. S4).

\section{Experimental Design and Litterbags Design}

We assigned litterbags to randomised locations within the study site (Fig. S5). The experiment comprised 273 litterbags in total: 105 used for analysis of $\mathrm{C}$ and $\mathrm{N}$ and for the determination of mass loss $(6$ filter treatments $\times 5$ replicates $\times 3$ collection times +5 replicate conventional litterbags $\times 3$ collection times) and 168 for PLFA analysis ( 6 filter treatments $\times 6$ replicates $\times 4$ collection times +5 replicate conventional litterbags $\times 4$ collection times). The design of the litterbags for the experiment followed that described by Pieristè et al. (2019a). The dimensions of the litterbags were $150-\mathrm{x}-150 \mathrm{~mm}$, with the upper part made from a sheet of perforated film filter material and the bottom part made from a sterile Teflon mesh sheet of pore sizes $0.1 \mathrm{~mm}$ allowing only microflora (fungi and bacteria) access to the litter (Fig. S6). Six different filter treatments were created (Fig. S1): a "Full-spectrum" treatment (full-spectrum at near-ambient sunlight) of polyethene film (0.05 mm thick, 04 PE-LD; Etola, Jyväskylä, Finland) transmitting $>95 \%$ of incident PAR and UV radiation; a "No-UV-B" treatment (attenuating UV-B radiation $<320 \mathrm{~nm}$ ) using polyester ( $0.125 \mathrm{~mm}$ thick, Autostat CT5; Thermoplast, Helsinki, Finland); a "No-UV" treatment using Rosco \#226 (0.2 mm thick, Westlighting, Helsinki, Finland) attenuating UV radiation $<380 \mathrm{~nm}$; a "No-UV/ Blue" treatment using Rosco \#312 Canary yellow (0.2 mm thick, Westlighting, Helsinki, Finland) attenuating UV radiation and blue light $<480 \mathrm{~nm}$; a "No-UV/ Blue/Green" treatment using Rosco \#135 deep golden amber (0.2 mm thick, Westlighting, Helsinki, Finland) attenuating UV radiation and blue and green light $<580 \mathrm{~nm}$; and a "Dark" treatment using solid polyethene film, white on the upper-side and solid black on the lowerside $(0.15 \mathrm{~mm}$ thick, Casado sarl, France), attenuating $>95 \%$ of PAR and UV radiation. In addition, a treatment 
(henceforth "mesh") made from classic litterbags with mesh size $0.1 \mathrm{~mm}$ was included to test differences between our litterbags and classical litterbag used in decomposition studies. There were no significant differences in mass loss $(p=0.541),[\mathrm{C}](p=0.888)$ and $[\mathrm{N}](p=0.123)$ between the full-spectrum treatment and the mesh treatment (Table S17, Fig. S13). However, the full-spectrum treatment had a lower C:N (20.5) than the mesh treatment (21.9) ( $p=0.024$, Table S17, Fig. S13).

Litterbags were deployed on 05-Dec-2017, to coincide with the end of leaf fall and follow the natural timing of decomposition as faithfully as possible. They were pinned to the soil surface with small tent pegs, through a homogeneous thin layer of the previous years' litter that remained in contact with the underside of the litterbags. Once a week, any debris that fell on the litterbags was removed, to assure that they remained uncovered in order to avoid any confounding effects.

\section{Litter Material}

Fully senescent "sun" leaves from European beech (Fagus sylvatica L.) trees were collected directly from trees on the southern border of the stand in the Forêt Verte, Rouen, France (49 $\left.30^{\prime} 17.0^{\prime \prime} \mathrm{N} 1^{\circ} 06^{\prime} 44.9^{\prime \prime} \mathrm{E}\right)$. The petiole was removed from the leaves before they were scanned to obtain leaf area calculated with the software WinFOLIA (Image analysis for plant science, Regent Instruments Inc., Nepean, Canada). Immediately after sampling, both the adaxial (upper) and abaxial (lower) epidermal flavonoid content and leaf chlorophyll content were optically assessed using a Dualex Scientific + (ForceA, Paris Orsay, France) device in order to verify that there were no initial differences in their pigmentation or epidermal UV transmittance (Table S2). The leaves were then oven-dried at $37^{\circ} \mathrm{C}$ for one week and reweighed to obtain their dry weight (DW) (Table S2). Entire leaves were placed inside litterbags with the adaxial leaf epidermis facing up in a single layer (consisting of 4-5 leaves per litterbag, weighing 300$400 \mathrm{mg}$, Table S2).

\section{Litter Mass Remaining, Carbon and Nitrogen Content}

Five replicate litterbags from each treatment combination were collected after 1, 3 and 6 months. After collection, litter was dried at $37{ }^{\circ} \mathrm{C}$, cleaned with small brushes to eliminate any soil particles and worm casts present in most samples, and weighed on a precision balance (Entris 224i-1S, Sartorius Lab Instruments GmbH \& Co. KG, Göttingen, Germany). The litter was then ground to a fine powder, and 3-4 mg DW was used to determine the percentage $[\mathrm{C}]$ and $[\mathrm{N}]$ content using a CN Soil Analyzer Flash 2000 (Thermo Scientific, Waltham, USA), and calculate the carbon to nitrogen ratio $(\mathrm{C}: \mathrm{N})$. Ash free dry mass (AFDM) was determined by combustion of a subsample of each replicate in a muffle oven at $550{ }^{\circ} \mathrm{C}$ for $12 \mathrm{~h}$ to allow quantification of mineral contamination.

\section{PLFA and NLFA Analysis}

Six replicate litterbags from each treatment combination were collected after 1, 2, 3 and 6 months. An extra collection time was included for these analyses as we expected the microbial biomass to vary more within the first 3 months than the amount mass loss or C. After collection, litter was freeze-dried, to conserve the samples until PLFA (phospholipid-derived fatty acids) and NLFA (neutral lipid fatty acids) analyses could be performed. Freeze-dried litter was ground and a subsample $0.15 \mathrm{~g}$ (from each litterbag) was used to determine the fatty acid content. Lipid extraction was performed according to Frostegård et al. (1991). The extracted lipids were fractionated into neutral lipids, glycolipids and polar lipids on a SPE silica- column (Solid Phase Extraction, Hypersep SILICA $500 \mathrm{mg}$ from Thermo Scientific) by successive elution with chloroform, acetone and methanol. NLFA and PLFA were then concentrated under a nitrogen stream, re-dissolved in toluene/ methanol (1:1) and subjected to a trans-esterification using a base solution $(0.2 \mathrm{M} \mathrm{KOH}$ prepared in methanol) at $37^{\circ} \mathrm{C}$ for $15 \mathrm{~min}$ to release free fatty acid methyl esters from the PLFA and the NLFA. Fatty-acid methyl esters (FAMEs) were compared to nonadecanoic acid methyl ester (C19:0-Me) as an internal standard: identified by comparing retention times against those of a range of standards (fatty acid methyl ester mixtures C4-C24:1, Sigma- Aldrich) and quantified according to their mass (vs known mass of an internal standard). The final extracts were analysed and FAMEs were characterised by Fast GC-MS. Samples were injected in split mode (ratio 100.0 ) at $280^{\circ} \mathrm{C}$. The separation was performed on a Zebron ZB-1 MS capillary column (10 m length $\times 0.1 \mathrm{~mm}$ i.d., $0.1 \mu \mathrm{m}$ film thickness (Phenomenex, USA). The system was operated at constant linear velocity $\left(40 \mathrm{~cm} \mathrm{~s}^{-1}\right)$ using helium as the carrier gas and the oven was programmed as follow: 
heated from $175{ }^{\circ} \mathrm{C}$ to $275{ }^{\circ} \mathrm{C}$ (at $25^{\circ} \mathrm{C} \mathrm{min}{ }^{-1}$ ) and subsequently maintained at this temperature for $30 \mathrm{~s}$ in a Gas Chromatograph (Shimadzu 2010 Plus System, Shimadzu Corporation, Kyoto, Japan). This GC was equipped with a Shimadzu QP 2010 Ultra mass spectrometer detector (Shimadzu Corporation) and a Flam Ionization Detector $\left(300{ }^{\circ} \mathrm{C}\right)$ used alternately. Fatty acids were identified by comparing their mass spectra with the standard mass spectra in the NIST MS library. The amounts of the NLFA 16:1 155 and the PLFA $16: 1 \omega 5$ in the litter were determined and the ratio used as an indicator of AMF (arbuscular mycorrhizal fungi) biomass. The PLFA c18:2 26,9 was used as an indicator of saprotrophic fungal biomass (Frostegård et al., 1991). The biomass of Gram-positive bacteria (Gram-P) was estimated by the quantification of the PLFA: i15:0, a15:0, i16:0, i17:0, a17:0 and Gram-negative bacteria (Gram-N) by the quantification of the PLFA: cy17:0, c18:1 1 7 and cy 19:0 in the litter (Frostegård et al. 2011). The Gram-P biomass to Gram-N biomass ratio (Gram$\mathrm{P}$ :Gram-N) was also calculated. The fungal-to-bacterial biomass ratio (F:B) was calculated, and the total amount of PLFA was used as an indicator of total microbial biomass in each sample.

\section{Data Analysis}

Treatment effects on AFDM, [C], [N], C:N, fungal and bacterial biomass, total microbial biomass, F:B, Gram-P biomass, Gram-N biomass and Gram-P:Gram-N, were tested using a two-way ANOVA with fixed experimental factors: filter and time and the interaction between them. The normal distribution of the residuals and homoscedasticity of variance were checked when performing the statistical analyses. Where a significant $(p<0.05)$ interaction was given by the ANOVA, the pairwise comparisons were tested (Function glht in Package Multicomp). Holm's adjustment was used to account for multiple pairwise comparisons. Abundances of individual PLFA biomarkers were used as input values for the non-metric multidimensional scaling analysis (NMDS), to check for differences among the microbial communities in the different filter treatments, using the package 'vegan' (Oksanen et al. 2019). The Bray-Curtis similarity index was employed in the analysis. PERMANOVA with function adonis() in the package 'vegan' (Oksanen et al. 2019) with filter treatment and time as fixed factor was performed and followed by post-hoc test pairwise.adonis() with Holm's correction to allow us to evaluate differences between treatments (Martinez Arbizu 2019). Additionally, SIMPER test was applied to estimate the contribution of the individual PLFA biomarkers to dissimilarity between the different treatments. Correlations between litter quality $(\mathrm{C}$ and $\mathrm{N}$ content) and decomposer assemblages (PLFAs) were inspected with the functions cor() and cor_pmat() in package 'ggcorrplot' (Kassambara 2019). All statistical analyses were performed in R version 3.3 .3 (2017).

\section{Results}

Litter Mass Remaining, Carbon and Nitrogen Content

The effect of our filter treatments on remaining AFDM of leaf litter varied according to the time of exposure (interaction filter-treatment-by-time: $p=0.009$, Table 1) and became significant only at the end of the experiment (Fig. 1), with the Dark treatment having higher AFDM remaining than the No-UV $(+15.2 \%)$ and No-UVB $(+14.9 \%)$ treatments (pairwise comparison Dark - NoUV: $p=0.012$, Dark - No-UVB: $p=0.016$, Table S3). Over the 6 months of the experiment, mass loss was about 20\% (Fig. 1).

Filter treatment did not have a significant effect on litter $[\mathrm{C}](p=0.800$, Table 1, Fig. 2), but did impact $[\mathrm{N}]$ $(p=0.034$, Table 1, Fig. 2) and consequently the C:N $(p=0.031$, Table 1, Fig. 2). This resulted in litter in the Dark treatment having a higher $[\mathrm{N}]$ (pairwise comparisons Dark - No-UVB: $p<0.001$, Dark - No-UV $p=$ 0.029 , Table S4) than litter in the No-UVB $(+155.9 \%)$ and No-UV $(+120.9 \%)$ treatments, and a lower $\mathrm{C}: \mathrm{N}$ (pairwise comparison Dark - No-UVB: $p=0.014$ ) than litter in the No-UVB treatment, at the end of the experiment (Fig. 2, Table S5).

\section{Microbial Biomass}

Total PLFA, a surrogate for microbial biomass on the litter samples, increased with time $(p<0.001$, Table 2 , Fig. S7) and was affected by our filter treatments ( $p=$ 0.022 , Table 2, Fig. 3) consistently over time (interaction filter-treatment-by-time: $p=0.370$, Table 2). Litter under the No-UV/Blue/Green treatment had higher microbial biomass than litter in the No-UVB $\left(+221.4 \mu \mathrm{g} \mathrm{g}^{-1}\right)$ treatment (pairwise comparison NoUV/Blue/Green - No-UVB: $p=0.006$, Fig. 3, Table S6). 
Table 1 Anova results for two fixed factors (filter treatment: with 6 levels and time with 3 levels) and their interactions on single dependent variables: Ash Free Dry Mass (AFDM) remaining, carbon content, nitrogen content and C:N ratio. Degrees of freedom (d.f.), sum of squares (SS), mean square (MS), F statistic (f) and $p$ value $(p)$. Significant terms are shown in bold. Nonsignificant terms were retained since dropping them did not significantly affect the model. One sample was unusable for AFDM and [C] analyses so these residual d.f. are 71 rather than 72

\begin{tabular}{|c|c|c|c|c|c|}
\hline & d.f. & SS & MS & $\mathbf{F}$ & $p$ \\
\hline \multicolumn{6}{|l|}{ Variable: AFDM } \\
\hline Filter treatment & 5 & 216.94 & 43.39 & 1.318 & 0.266 \\
\hline Time & 2 & 552.17 & 276.08 & 8.388 & $<0.001$ \\
\hline Filter treatment $x$ Time & 10 & 860.97 & 86.097 & 2.616 & 0.009 \\
\hline Residuals & 71 & 2336.81 & 32.913 & & \\
\hline \multicolumn{6}{|l|}{ Variable: Carbon content } \\
\hline Filter treatment & 5 & 70.92 & 14.18 & 0.467 & 0.800 \\
\hline Time & 2 & 1008.40 & 504.20 & 16.593 & $<0.001$ \\
\hline Filter treatment $\mathrm{x}$ Time & 10 & 536.33 & 53.63 & 1.765 & 0.083 \\
\hline Residuals & 71 & 2157.46 & 30.39 & & \\
\hline \multicolumn{6}{|l|}{ Variable: Nitrogen content } \\
\hline Filter treatment & 5 & 30,654 & 6131 & 2.5632 & 0.034 \\
\hline Time & 2 & 88,652 & 44,326 & 18.526 & $<0.001$ \\
\hline Filter treatment $x$ Time & 10 & 50,776 & 5078 & 2.122 & 0.033 \\
\hline Residuals & 72 & 172,270 & 2393 & & \\
\hline \multicolumn{6}{|l|}{ Variable: $\mathrm{C}: \mathrm{N}$ ratio } \\
\hline Filter treatment & 5 & 416.67 & 83.33 & 2.620 & 0.031 \\
\hline Time & 2 & 2674.62 & 1337.31 & 42.037 & $<0.001$ \\
\hline Filter treatment $x$ Time & 10 & 245.75 & 24.58 & 0.773 & 0.655 \\
\hline Residuals & 72 & 2290.52 & 31.81 & & \\
\hline
\end{tabular}

The biomass of both bacteria and fungi followed the same temporal pattern as total microbial biomass, increasing over the course of the experiment $(p<0.001$ in both cases, Table 2, Fig. S7, Fig. S8) and both were also affected by our filter treatments $(p=0.001$ and $p=0.021$ respectively, Table 2, Fig. 3); an effect that remained constant through time (filter treatment-by-time interaction: $p=0.270$ and $p=0.390$ respectively, Table 2). Fungal biomass was higher in the No-UV/Blue/Green treatment than the No-UVB $\left(+209.6 \mu \mathrm{g} \mathrm{g}^{-1}\right)$ treatment (pairwise comparison: No-UV/Blue/Green - No-UVB: $p=0.006$, Fig. 3, Table S7). On the other hand, bacterial biomass was lower in the Dark treatment than the other treatments (Fig.3, Table S8), and consequently, the F:B ratio of the Dark treatment was highest (Fig. 3, Table S9). The filter treatments had an effect on the biomass of both Gram-P ( $p=0.001$, Table 2) and Gram-N bacteria ( $p=0.029$, Table 2$)$. The biomass of Gram-P was lower in the Dark treatment than the other treatments (Fig. 3, Table S10), while the biomass of Gram-N was higher in the No-UV/Blue/Green treatment than the No-UVB $\left(+4.4 \mu \mathrm{g} \mathrm{g}^{-1}\right)$ treatment (pairwise comparison: No-UV/Blue/Green - No-UVB: $p=$ 0.034, Fig. 3, Table S11).

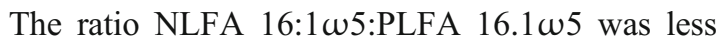
than 1 in all the samples (Fig. S9), therefore we concluded that no AMF were present in our samples.

\section{Microbial Assemblages}

The greatest change in composition of PLFA biomarkers occurred over time $(p=0.001$, Table 3, Fig. 


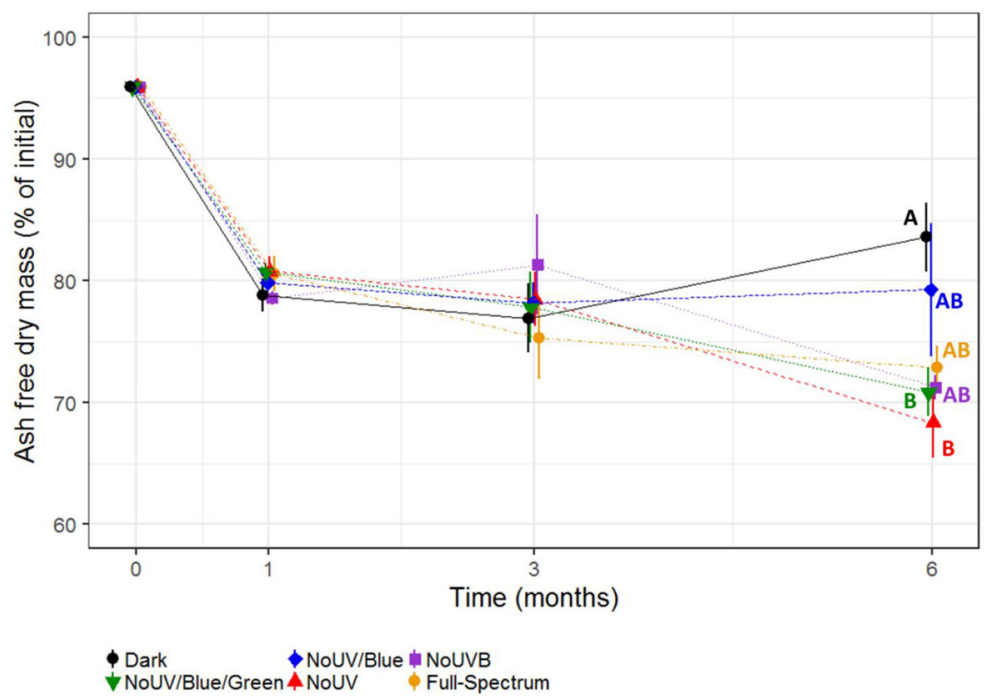

Fig. 1 Remaining ash free dry mass (AFDM) as a percentage of initial weight for each filter treatment after each sampling period over the 6 months of the experiment. Means \pm SE are shown $(n=$ 5). Letters indicate significant differences between filter treatments at the end of the experiment. Symbols represent the following filter treatments: $\bullet$ black = "Dark" (attenuating $>95 \%$ of PAR and UV radiation); $\boldsymbol{\nabla}$ green = "No-UV/Blue/Green" (attenuating UV radiation and blue and green light $<580 \mathrm{~nm}$ ); $\bullet$ blue = "No-UV/ Blue" (attenuating UV radiation and blue light $<480 \mathrm{~nm}$ ); red = "No-UV" (attenuating UV radiation $<380 \mathrm{~nm}$ ); - purple $=$ " No-UV-B" (attenuating UV-B radiation $<320 \mathrm{~nm}$ ); $\circ$ yellow = " Full-spectrum" (transmitting $>95 \%$ of incident PAR and UV radiation). Pairwise comparisons between filter treatments are given in Table S3

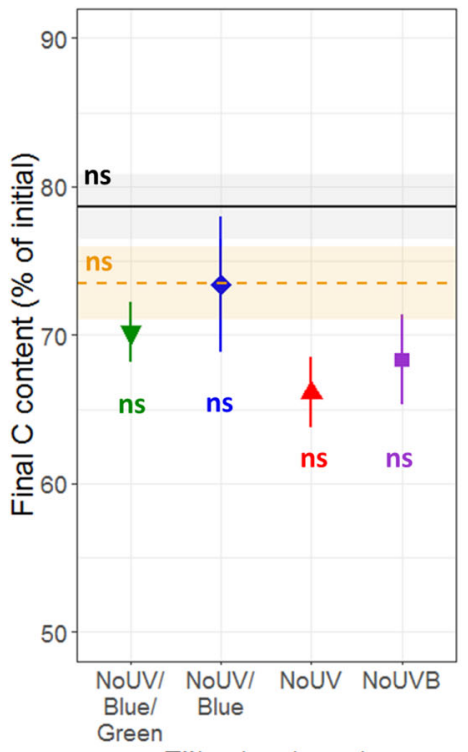

Filter treatment

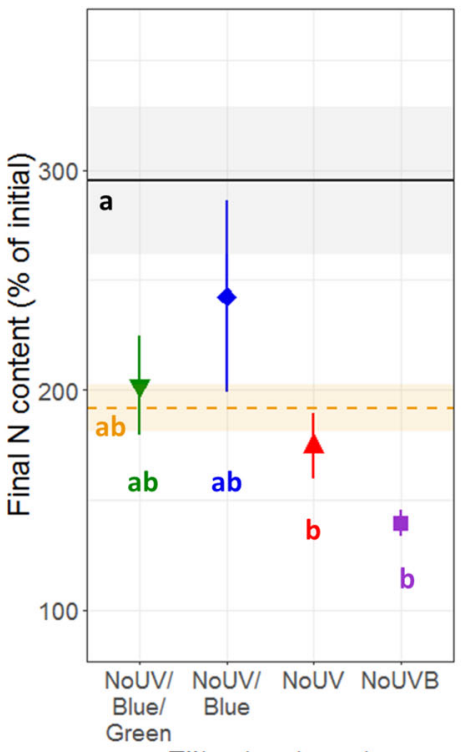

Filter treatment

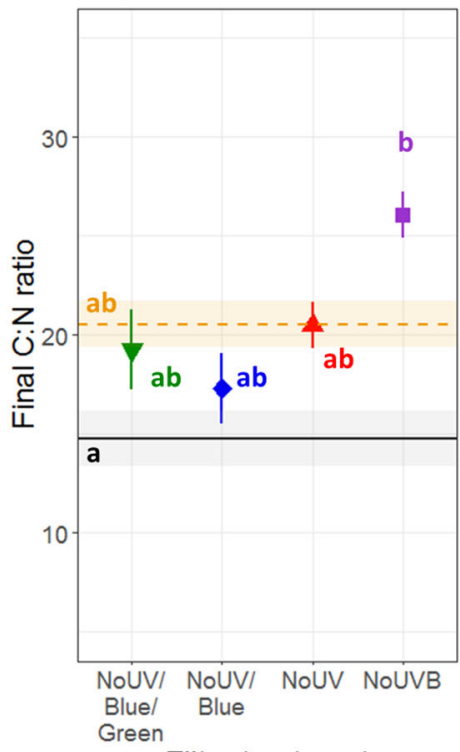

Filter treatment

- Dark $₹$ NoUV/Blue/Green

Fig. 2 Final $\mathrm{C}$ content, $\mathrm{N}$ content and $\mathrm{C}: \mathrm{N}$ ratio for each filter treatment. Means $\pm \mathrm{SE}$ are shown $(n=5)$. Letters show significant differences between filter treatments, while "ns" stands for "nonsignificant". Symbols represent the following filter treatments: $\boldsymbol{\nabla}$ green = "No-UV/Blue/Green" (attenuating UV radiation and blue and green light $<580 \mathrm{~nm}$ ); $\bullet$ blue $=$ "No-UV/Blue" (attenuating UV radiation and blue light $<480 \mathrm{~nm}$ ); $\boldsymbol{\Delta}$ red = "No-UV" (attenuating UV radiation $<380 \mathrm{~nm}$ ); - purple = "No-UV-B"
NoUV/Blue NoUV

(attenuating UV-B radiation $<320 \mathrm{~nm}$ ). The solid black line represents the mean of the "Dark" treatment (attenuating $>95 \%$ of PAR and UV radiation) and the shaded areas around it represent the SE. The dashed yellow line represents the mean of the "Fullspectrum" treatment (transmitting $>95 \%$ of incident PAR and UV radiation) and the shaded areas around it represent the SE. Pairwise comparisons between time and filter treatment are given in Tables S4 and S5 
Table 2 Anova results for two fixed factors (filter treatment: with 6 levels and time with 4 levels) and their interactions on single dependent variables: microbial biomass, bacterial biomass, fungal biomass, F:B ratio, Gram-P bacteria biomass, Gram-N bacteria biomass, Gram-P:Gram-N. Degrees of freedom (d.f.), sum of squares (SS), mean square (MS), f statistic (f) and $p$ value ( $p$ ). Significant terms are shown in bold. Non-significant terms were retained since dropping them did not significantly affect the model. One sample was unusable for PLFA analyses so these residual d.f. are 119 rather than 120

\begin{tabular}{|c|c|c|c|c|c|}
\hline & d.f. & SS & MS & $\mathbf{F}$ & $p$ \\
\hline \multicolumn{6}{|c|}{ Variable: Microbial biomass } \\
\hline Filter treatment & 5 & 606,246 & 121,249 & 2.749 & 0.022 \\
\hline Time & 3 & $2,972,335$ & 990,778 & 22.462 & $<0.001$ \\
\hline Filter treatment $\mathrm{x}$ Time & 15 & 723,027 & 48,202 & 1.093 & 0.370 \\
\hline Residuals & 119 & $5,248,886$ & 44,108 & & \\
\hline \multicolumn{6}{|c|}{ Variable: Bacterial biomass } \\
\hline Filter treatment & 5 & 7149 & 1430 & 4.285 & 0.001 \\
\hline Time & 3 & 126,353 & 42,118 & 126.216 & $<0.001$ \\
\hline Filter treatment $\mathrm{x}$ Time & 15 & 6085 & 406 & 1.216 & 0.270 \\
\hline Residuals & 119 & 39,710 & 334 & & \\
\hline \multicolumn{6}{|l|}{ Variable: Fungal biomass } \\
\hline Filter treatment & 5 & 548,902 & 109,780 & 2.774 & 0.021 \\
\hline Time & 3 & $1,956,270$ & 652,090 & 16.480 & $<0.001$ \\
\hline Filter treatment $\mathrm{x}$ Time & 15 & 635,744 & 42,383 & 1.071 & 0.390 \\
\hline Residuals & 119 & $4,708,723$ & 39,569 & & \\
\hline \multicolumn{6}{|l|}{ Variable: F:B ratio } \\
\hline Filter treatment & 5 & 152 & 30 & 5.574 & $<0.001$ \\
\hline Time & 3 & 385 & 128 & 23.493 & $<0.001$ \\
\hline Filter treatment $\mathrm{x}$ Time & 15 & 58 & 4 & 0.713 & 0.767 \\
\hline Residuals & 119 & 645 & 5 & & \\
\hline \multicolumn{6}{|l|}{ Variable: Gram-P biomass } \\
\hline Filter treatment & 5 & 5403 & 1081 & 4.405 & 0.001 \\
\hline Time & 3 & 114,443 & 38,148 & 155.488 & $<0.001$ \\
\hline Filter treatment $\mathrm{x}$ Time & 15 & 4964 & 311 & 1.349 & 0.184 \\
\hline Residuals & 119 & 29,196 & 145 & & \\
\hline \multicolumn{6}{|c|}{ Variable: Gram-N biomass } \\
\hline Filter treatment & 5 & 307 & 61 & 2.593 & 0.029 \\
\hline Time & 3 & 519 & 173 & 7.306 & $<0.001$ \\
\hline Filter treatment $\mathrm{x}$ Time & 15 & 418 & 28 & 1.177 & 0.299 \\
\hline Residuals & 119 & 2815 & 24 & & \\
\hline \multicolumn{6}{|c|}{ Variable: Gram-P: Gram-N ratio } \\
\hline Filter treatment & 5 & 15 & 3 & 5.079 & $<0.001$ \\
\hline Time & 3 & 200 & 67 & 112.275 & $<0.001$ \\
\hline Filter treatment $x$ Time & 15 & 16 & 1 & 1.785 & 0.045 \\
\hline Residuals & 119 & 71 & 1 & & \\
\hline
\end{tabular}



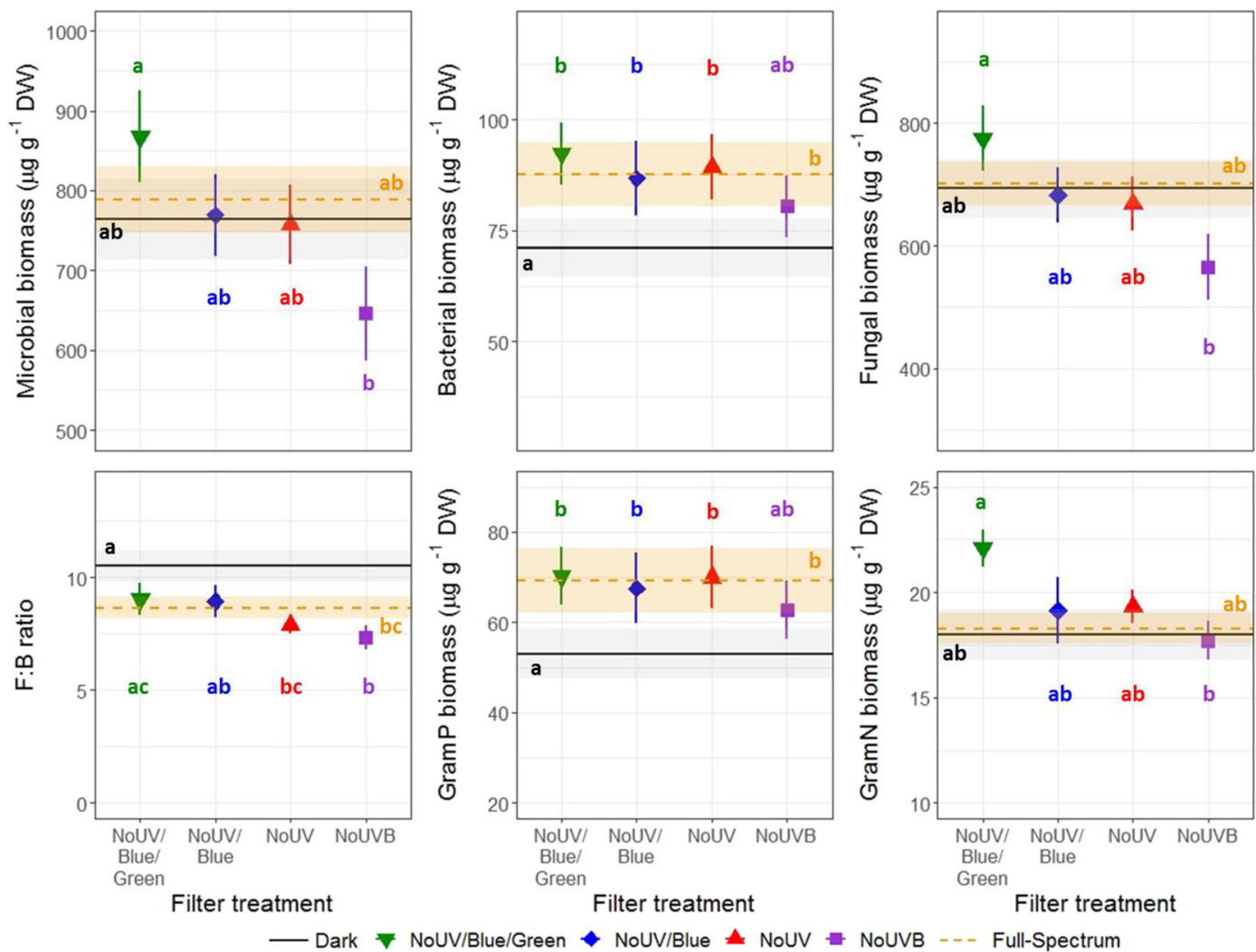

Fig. 3 Microbial biomass, bacterial biomass, fungal biomass, F:B ratio, Gram-P biomass and Gram-N biomass for each filter treatment pooled over the entire 6 months of the experiment. Means \pm $\mathrm{SE}$ are shown $(n=24)$. Letters show significant differences between filter treatments. Symbols represent the following filter treatments: $\boldsymbol{\nabla}$ green = "No-UV/Blue/Green" (attenuating UV radiation and blue and green light $<580 \mathrm{~nm}$ ); blue = "No-UV/ Blue" (attenuating UV radiation and blue light $<480 \mathrm{~nm}$ ); $\boldsymbol{\Delta}$ red = "No-UV" (attenuating UV radiation $<380 \mathrm{~nm}$ ); - purple = "

S11) which explained $31.9 \%$ of the variation, while the filter treatment ( $p=0.001$, Table 3, Fig. 4, Fig. S11) accounted only for $10.9 \%$. There was no interaction between time and filter treatment $(p=0.185$, Table 3$)$. The No-UV/Blue/Green and the No-UVB treatments were the two most different treatments (pairwise comparison: $p=0.015$, Table S13) with an overall dissimilarity of $27.1 \%$. The fungal PLFA biomarker C18:2w6,9 alone accounted for $84.4 \%$ of this difference (Table S14). However, when separating the four collection times, an effect of the filter treatment was found only after one month ( $p=0.004$, Table 3 , Fig. 4$)$, and, individually, the Dark treatment and the No-UV/Blue/ Green treatments each differed from the No-UV treatment (pairwise comparisons respectively: $p=0.030$ and $p=0.042$, Table S15). The fungal PLFA biomarker
No-UV-B" (attenuating UV-B radiation $<320 \mathrm{~nm}$ ). The solid black line represents the mean of the "Dark" treatment (attenuating $>95 \%$ of PAR and UV radiation) and the shaded areas around it represent the SE. The dashed yellow line represents the mean of the "Full-spectrum" treatment (transmitting $>95 \%$ of incident PAR and UV radiation) and the shaded areas around it represent the SE. Pairwise comparisons between time and filter treatment are given in Tables S6-S11 and details on separate collection times are given in Fig. S7

C18:2w6,9 alone accounted for most of the difference between these two treatments $(87.7 \%$ and $87.4 \%$ respectively with dissimilarity $20.6 \%$ and $20.5 \%$ respectively, Table S16).

\section{Litter Quality and Microbial Assemblages}

Generally, the different microbial variables were only weakly correlated with litter quality (Fig. S12). For instance, $[\mathrm{C}]$ was positively correlated with $\mathrm{F}: \mathrm{B}\left(\mathrm{R}^{2}=\right.$ $0.4, p<0.001)$, while it was negatively correlated with Gram-P biomass $\left(\mathrm{R}^{2}=-0.5, p<0.001\right)$; bacterial biomass $\left(\mathrm{R}^{2}=-0.4, p<0.001\right)$; microbial biomass $\left(\mathrm{R}^{2}=-\right.$ $0.2, p=0.050)$ and Gram-P:Gram-N $\left(\mathrm{R}^{2}=-0.4\right.$, $p<0.001)$. In contrast, $[\mathrm{N}]$ was positively correlated with Gram-P biomass $\left(\mathrm{R}^{2}=0.4, p<0.001\right)$; bacterial 
Table 3 Permanova results for two fixed factors (filter treatment: with 6 levels and time with 4 levels) and for one fixed factor (filter treatment) at the four collection times, after NMDS on PLFA markers. Degrees of freedom (d.f.), sum of squares (SS), mean square (MS), F model (F mod), $\mathrm{R}^{2}$ and $p$ value $(p)$. Significant terms are shown in bold. Non-significant terms were retained since dropping them did not significantly affect the model

\begin{tabular}{|c|c|c|c|c|c|c|}
\hline & Df & SS & MS & $F \bmod$ & $\mathbf{R}^{2}$ & $p$ \\
\hline Filter treatment & 5 & 0.503 & 0.101 & 5.319 & 0.115 & 0.001 \\
\hline Time & 3 & 1.297 & 0.432 & 22.880 & 0.296 & 0.001 \\
\hline Filter treatment $\mathrm{x}$ Time & 15 & 0.367 & 0.024 & 1.295 & 0.838 & 0.185 \\
\hline Residuals & 117 & 2.212 & 0.019 & & 0.505 & \\
\hline Total & 140 & 4.379 & & & 1.000 & \\
\hline \multicolumn{7}{|l|}{1 month } \\
\hline Filter treatment & 5 & 0.288 & 0.058 & 3.494 & 0.368 & 0.004 \\
\hline Residuals & 30 & 0.495 & 0.017 & & 0.632 & \\
\hline Total & 35 & 0.784 & & & 1.000 & \\
\hline \multicolumn{7}{|l|}{2 months } \\
\hline Filter treatment & 5 & 0.124 & 0.025 & 1.110 & 0.161 & 0.379 \\
\hline Residuals & 29 & 0.649 & 0.022 & & 0.839 & \\
\hline Total & 34 & 0.774 & & & 1.000 & \\
\hline \multicolumn{7}{|l|}{3 months } \\
\hline Filter treatment & 5 & 0.167 & 0.033 & 2.016 & 0.265 & 0.083 \\
\hline Residuals & 28 & 0.464 & 0.017 & & 0.735 & \\
\hline Total & 33 & 0.631 & & & 1.000 & \\
\hline \multicolumn{7}{|l|}{6 months } \\
\hline Filter treatment & 5 & 0.158 & 0.032 & 2.034 & 0.260 & 0.056 \\
\hline Residuals & 29 & 0.450 & 0.016 & & 0.740 & \\
\hline Total & 34 & 0.608 & & & 1.000 & \\
\hline
\end{tabular}

biomass $\left(\mathrm{R}^{2}=0.4, p=0.001\right)$; microbial biomass $\left(\mathrm{R}^{2}=\right.$ $0.3, p=0.016)$ and fungal biomass $\left(\mathrm{R}^{2}=0.2, p=0.030\right)$, but negatively correlated with $\mathrm{F}: \mathrm{B}\left(\mathrm{R}^{2}=-0.2, p=\right.$ $0.030)$. Moreover, $\mathrm{C}: \mathrm{N}$ was positively correlated with $\mathrm{F}: \mathrm{B}\left(\mathrm{R}^{2}=0.4, p<0.001\right)$, but negatively correlated with Gram-P biomass $\left(\mathrm{R}^{2}=-0.5, p<0.001\right)$; bacterial biomass $\left(\mathrm{R}^{2}=-0.5, p<0.001\right)$; fungal biomass $\left(\mathrm{R}^{2}=-\right.$ $0.3, p=0.006)$; microbial biomass $\left(\mathrm{R}^{2}=-0.3, p=\right.$ $0.001)$ and Gram-P:Gram-N $\left(\mathrm{R}^{2}=-0.5, p<0.001\right)$.

\section{Discussion}

In our study, leaf litter lost about $20-25 \%$ of its initial mass during the first 6 months of decomposition. This mass loss was strongly affected by the interaction between filter treatments and time. This became evident after 6 months, whereby exclusion of the full spectrum, and likewise exclusion of both UV and blue light, caused slower decomposition than the other filter treatments (Fig. 1). This result is consistent with trends among filter treatments from the previous year (2016-2017) at the same site (Pieristè et al. 2019a). The previous study examined decomposition of leaf litter from three tree species, including European beech, and together these studies confirm that sunlight plays a role in litter decomposition in temperate forests. The effect of sunlight on mass loss in 2017-2018 (+15\% of mass lost) was lower than in 20162017 (+30\%) (Pieristè et al. 2019a), despite the LAI being the same during the two years (data not shown). This might be explained by the higher rainfall during the 2017-2018 study: $622.9 \mathrm{~mm}$, accumulated between 


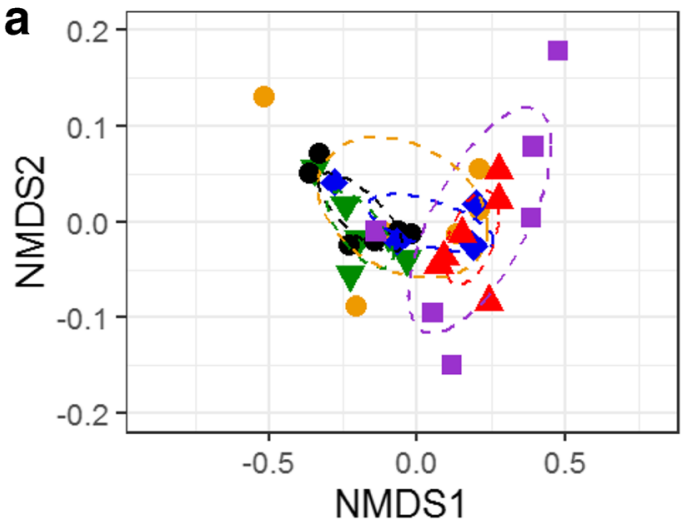

C

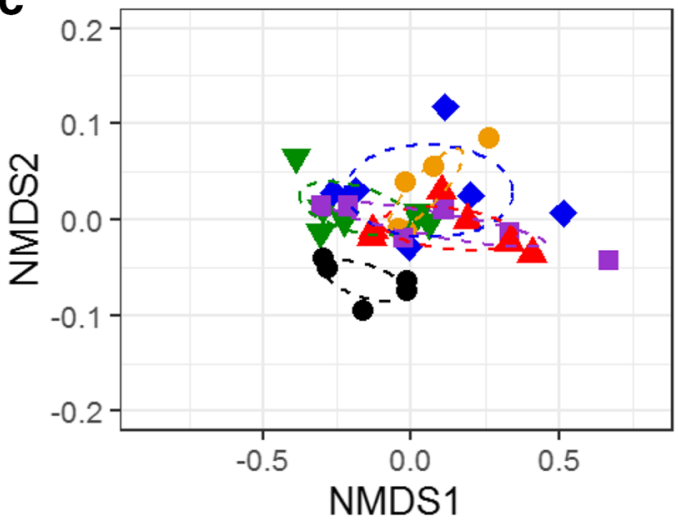

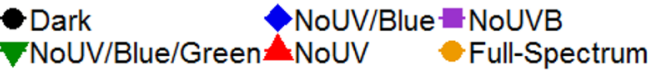

Fig. 4 Patterns of PLFA-biomarker composition mapped against the explanatory variable Filter at different collection times: a) 1 month (stress $=0.027$ ); b) 2 months (stress $=0.018$ ); c) 3 months $($ stress $=0.024)$ and d) 6 months (stress $=0.021)$, using non-metric multidimensional scaling (NMDS). Symbols represent the following filter treatments: $\bullet$ black = "Dark" (attenuating $>95 \%$ of PAR and UV radiation); $\boldsymbol{\nabla}$ green = "No-UV/Blue/Green" (attenuating UV radiation and blue and green light $<580 \mathrm{~nm}$ ); blue $=$ "NoUV/Blue" (attenuating UV radiation and blue light $<480 \mathrm{~nm}$ );

Dec 2017 and June 2018, compared with $314.8 \mathrm{~mm}$ during the same period in 2017 ("Rouen-Boos" weather station: http://www.infoclimat.fr). Differences in precipitation elsewhere have been found to produce large variations in photodegradation: for instance in a semi-arid environment, where the effect of photodegradation also decreased with increased precipitation (Brandt et al. 2007). In a temperate mesic forest, high precipitation and relative humidity can create a morefavourable environment for microbial development (Salamanca et al. 2003; Zhou et al. 2018), thus the relative benefit to microbial decomposition from photofacilitation is likely to be smaller than in arid environments.
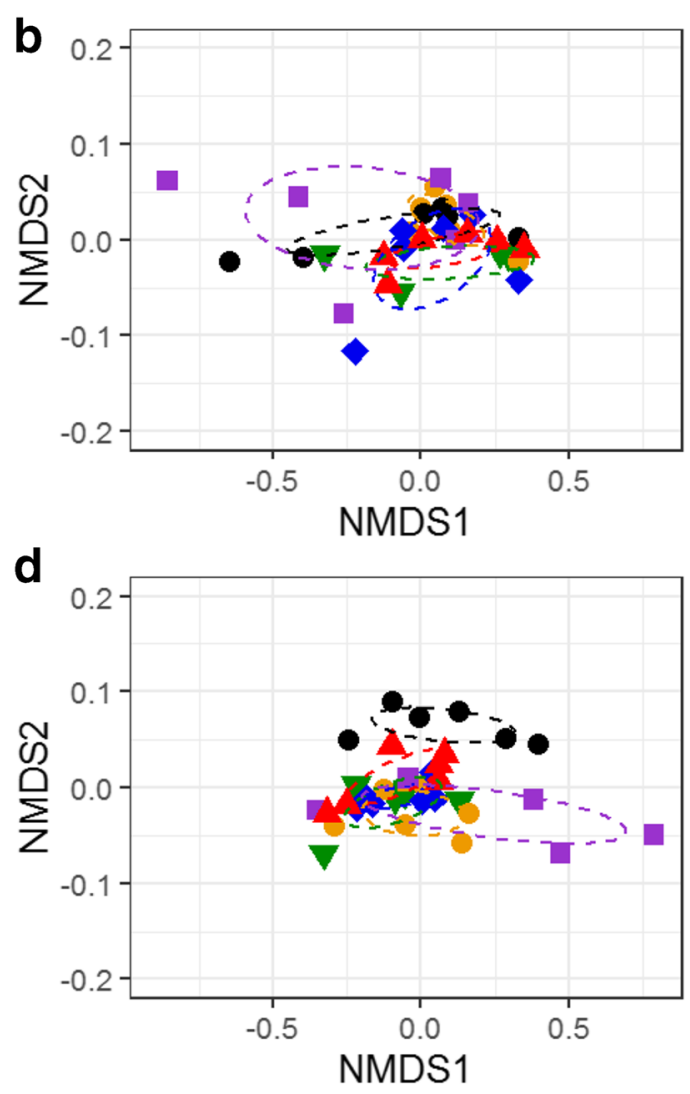

red = "No-UV" (attenuating UV radiation $<380 \mathrm{~nm}$ ); - purple $=$ " No-UV-B" (attenuating UV-B radiation $<320 \mathrm{~nm}$ ); ○ yellow = " Full-spectrum" (transmitting $>95 \%$ of incident PAR and UV radiation). The No-UV/Blue/Green ( $\boldsymbol{\nabla}$ green) and the No-UVB (- purple) treatments were the two most different treatments. When separating the four collection times, an effect of the filter treatment was found only after one month $(p=0.004$, Table 3$)$. More details are given in Tables S13-S16 and Fig. S11

In our study the effect of photodegradation on microbial biomass was small. Across different filter treatments, this modest impact tallied with the modest effect on mass loss associated with successive spectral regions (Figs. 1 \& 3). Moreover, previous studies showed the effects of UV radiation on microbial biomass and activity to be dependent on their interaction with other factors that can affect microbial activity, such as temperature, moisture and nutrient availability (Belnap et al. 2008; Gunasekera and Paul 2007; Rangel et al. 2004). In general, time was the most determinant factor affecting not only litter mass, but also microbial biomass. Indeed, the inhibitory effect of UV-B radiation in wet 
environments is small and variable across different timescales depending on the phase of decomposition considered (Barnes et al. 2015).

In our study, the F:B ratio was higher in treatments that excluded UV radiation and the blue-green region of the visible spectrum, due to a higher fungal biomass, suggesting that fungi are favoured by the exclusion of the short-wavelength regions of the solar spectrum (e.g. UV radiation, blue and green light). These results are in agreement with earlier findings that fungal growth and litter colonization are inhibited by supplemental UV radiation (Gehrke et al. 1995; Moody et al. 2001; Newsham et al. 1997; Verhoef et al. 2000) and ambient UV radiation in the leaf litter of some plant species (Pancotto et al. 2003). Moreover, green and blue light decreased hyphal length and the biomass of several fungi species in controlled conditions on a synthetic growing medium; suggesting fungi to prefer darker environments for their development (Velmurugan et al. 2010).

In our study, bacterial biomass was higher on litter receiving some sunlight rather than in darkness, suggesting that bacteria are facilitated in light compared to dark environments. This might be due to the greater nutrient availability for bacteria in these treatments as a consequence of photofacilitation (direct photomineralization). Several studies have found the process of photofacilitation of microbial decomposition to occur in arid and semi-arid ecosystems (Austin et al. 2016; Baker and Allison 2015; Lin et al. 2018). This might produce a divergence between microbial assemblages, with a tendency for photofacilitation of bacteria in sunlight where more simple nutrients are available, and fungi dominating in the dark where bacteria are unable to consume the complex substrates present. However, we cannot test this hypothesis with our study as further analysis of carbon quality would be required. Another factor possibly helping to segregate light and dark microbial assemblages, is the competitive relationship between bacteria and fungi previously observed in beech litter in a microcosm study (Møller et al. 1999), which may limit bacterial colonisation in the dark. In our study, it was not possible to distinguish the effect of photofacilitation from the direct effect of sunlight on microbial assemblages.

Our treatment excluding UV-B radiation tended to segregate from the other filter treatments, even though its effect on microbial community structure was not significantly different from the full-spectrum treatment. The No-UVB treatment had lower microbial and fungal biomass, and lower $\mathrm{F}: \mathrm{B}$, corresponding to lower [N] and
C:N. UV-B radiation carries more energy than UV-A radiation and visible light, implying higher potential for photochemical mineralization and consequent photofacilitation, but also for photoinhibition (Lin et al. 2015; Song et al. 2013). Hence, even at the low irradiances found in temperate forest understoreys UV$\mathrm{B}$ radiation can be important in shaping microbial communities, confirming previous findings from studies with supplemental lamps and high UV-B irradiances (Gehrke et al. 1995; Johnson 2003; Verhoef et al. 2000).

The structure of microbial assemblages, interpreted through the change in composition of PLFA biomarkers, varied during the course of the decomposition experiment in a manner that depended on the spectral composition, confirming the importance of sunlight in shaping microbial communities. The effect of sunlight on microbial decomposer communities has previously been found to change depending on the stage of decomposition (Pancotto et al. 2003; Pancotto et al. 2005). Our experiment examines only the initial 6-months of decomposition of beech leaf litter, when we expected effects of photodegradation on microbial biomass and assemblage structure to be most pronounced, and a longer study would be required to determine how microbial communities evolve later in the decomposition process. As decomposition proceeds, the potential role of interactions with other litter or soil biota in shaping microbial assemblages is also likely to become increasingly important (Coulibaly et al. 2019), adding further complexity to this process.

\section{Conclusion}

Our study shows that sunlight affects the microbial assemblages involved in the decomposition of leaf litter in temperate forests. Similar responses were previously recorded in arid environments and confirm the potential of photodegradation to affect microbes in a wavelengthdependent manner. Different regions of the solar spectrum affect microbial-assemblage structure and microbial biomass during the early stages of decomposition in a temperate forest understorey. UV radiation, and blue and green light, had a photoinhibitory effect on fungal decomposers; and are the key mediators of decomposition processes in temperate forest ecosystems, even at the very low irradiances occurring during winter and spring prior to canopy closure.

Acknowledgments We thank the ONF (Office National de Forêts) for the permission to use the study site. We would like to 
acknowledge the support of the PRESEN platform (FR SCALE 3730 CNRS; Normandie Université), and SoDa HelioClim-3 for the satellite data (Transvalor S.A., 694 avenue du Dr. Maurice Donat, 06255 Mougins, France).

Funding information Open access funding provided by University of Helsinki including Helsinki University Central Hospital. This research was funded by Academy of Finland decisions \#266523, \#304519 and \#324555 to TMR, personal EF project and a grant from the Region "Haute-Normandie" through the GRR-TERA SCALE (UFOSE Project) to MP.

Open Access This article is licensed under a Creative Commons Attribution 4.0 International License, which permits use, sharing, adaptation, distribution and reproduction in any medium or format, as long as you give appropriate credit to the original author(s) and the source, provide a link to the Creative Commons licence, and indicate if changes were made. The images or other third party material in this article are included in the article's Creative Commons licence, unless indicated otherwise in a credit line to the material. If material is not included in the article's Creative Commons licence and your intended use is not permitted by statutory regulation or exceeds the permitted use, you will need to obtain permission directly from the copyright holder. To view a copy of this licence, visit http://creativecommons.org/licenses/by/4.0/.

\section{References}

Almagro M, Martínez-López J, Maestre FT, Rey A (2017) The contribution of Photodegradation to litter decomposition in semiarid Mediterranean grasslands depends on its interaction with local humidity conditions, litter quality and position. Ecosystems 20:527-542. https://doi.org/10.1007/s10021016-0036-5

Anderson T-H, Domsch KH (1990) Application of ecophysiological quotients (qCO2 and $\mathrm{qD}$ ) on microbial biomasses from soils of different cropping histories. Soil Biol Biochem 22:251-255. https://doi.org/10.1016/0038-0717(90 )90094-G

Anderson T-H, Domsch KH (1993) The metabolic quotient for $\mathrm{CO} 2(\mathrm{qCO} 2)$ as a specific activity parameter to assess the effects of environmental conditions, such as ph, on the microbial biomass of forest soils. Soil Biol Biochem 25:393395. https://doi.org/10.1016/0038-0717(93)90140-7

Aphalo P, Albert A, Björn L, McLeod A, Robson TM, Rosenqvist E (2012) Beyond the visible: a handbook of best practice in plant UV photobiology. COST action FA0906 UV4growth, Helsinki

Aphalo P, Robson TM, Piiparinen J (2016) How to check an array spectrometer. Int Assoc Plant UV Res

Asplund J, Kauserud H, Bokhorst S, Lie MH, Ohlson M, Nybakken L (2018) Fungal communities influence decomposition rates of plant litter from two dominant tree species. Fungal Ecol 32:1-8. https://doi.org/10.1016/j. funeco.2017.11.003

Austin AT, Méndez MS, Ballaré CL (2016) Photodegradation alleviates the lignin bottleneck for carbon turnover in terrestrial ecosystems. Proc Natl Acad Sci 113:4392-4397. https://doi.org/10.1073/pnas.1516157113

Bais AF, Lucas RM, Bornman JF, Williamson CE, Sulzberger B, Austin AT, Wilson SR, Andrady AL, Bernhard G, McKenzie RLJP (2018) Environmental effects of ozone depletion, UV radiation and interactions with climate change: UNEP environmental effects assessment panel, update 2017. Photochemical \& Photobiological Sciences 17:127-179. https://doi.org/10.1039/C7PP90043K

Baker NR, Allison SD (2015) Ultraviolet photodegradation facilitates microbial litter decomposition in a Mediterranean climate. Ecology 96:1994-2003. https://doi.org/10.1890/141482.1

Baldrian P (2016) Forest microbiome: diversity, complexity and dynamics. FEMS Microbiol Rev 41:109-130. https://doi. org/10.1093/femsre/fuw040

Ball BA, Christman MP, Hall SJ (2019) Nutrient dynamics during photodegradation of plant litter in the Sonoran Desert. J Arid Environ 160:1-10. https://doi.org/10.1016/j. jaridenv.2018.09.004

Barnes PW, Throop HL, Archer SR, Breshears DD, McCulley RL, Tobler MA (2015) Sunlight and soil-litter mixing: drivers of litter decomposition in Drylands. In: U Lüttge, W Beyschlag (eds) Progress in botany: Vol 76. Springer International Publishing, Cham

Belnap J, Phillips SL, Flint S, Money J, Caldwell M (2008) Global change and biological soil crusts: effects of ultraviolet augmentation under altered precipitation regimes and nitrogen additions. Glob Chang Biol 14:670-686. https://doi. org/10.1111/j.1365-2486.2007.01509.x

Blanc P, Gschwind B, Lefèvre M, Wald L (2011) The HelioClim project: surface solar irradiance data for climate applications. Remote Sens 3:343-361. https://doi.org/10.3390/rs3020343

Brandt LA, King JY, Hobbie SE, Milchunas DG, Sinsabaugh RL (2010) The role of Photodegradation in surface litter decomposition across a grassland ecosystem precipitation gradient. Ecosystems 13:765-781. https://doi.org/10.1007/s10021010-9353-2

Brandt LA, King JY, Milchunas DG (2007) Effects of ultraviolet radiation on litter decomposition depend on precipitation and litter chemistry in a shortgrass steppe ecosystem. Glob Chang Biol 13:2193-2205. https://doi.org/10.1111/j.13652486.2007.01428.x

Coulibaly SFM, Winck BR, Akpa-Vinceslas M, Mignot L, Legras M, Forey E, Chauvat M (2019) Functional Assemblages of Collembola Determine Soil Microbial Communities and Associated Functions Frontiers in Environmental Science 7. doi: https://doi.org/10.3389/fenvs.2019.00052

Day TA, Bliss MS, Tomes AR, Ruhland CT, Guénon R (2018) Desert leaf litter decay: coupling of microbial respiration, water-soluble fractions and photodegradation. Glob Chang Biol 24:5454-5470. https://doi.org/10.1111/gcb.14438

Day TA, Guénon R, Ruhland CT (2015) Photodegradation of plant litter in the Sonoran Desert varies by litter type and age. Soil Biol Biochem 89:109-122. https://doi.org/10.1016 /j.soilbio.2015.06.029

Day TA, Zhang ET, Ruhland CT (2007) Exposure to solar UV-B radiation accelerates mass and lignin loss of Larrea tridentata litter in the Sonoran Desert. Plant Ecol 193:185-194. https://doi.org/10.1007/s11258-006-9257-6 
Duguay KJ, Klironomos JN (2000) Direct and indirect effects of enhanced UV-B radiation on the decomposing and competitive abilities of saprobic fungi. Appl Soil Ecol 14:157-164. https://doi.org/10.1016/S0929-1393(00)00049-4

Foereid B, Rivero MJ, Primo O, Ortiz I (2011) Modelling photodegradation in the global carbon cycle. Soil Biol Biochem 43:1383-1386. https://doi.org/10.1016/j. soilbio.2011.03.004

Fourtouni A, Manetas Y, Christias C (1998) Effects of UV$\mathrm{B}$ radiation on growth, pigmentation, and spore production in the phytopathogenic fungus Alternaria solani. Can J Bot 76:2093-2099. https://doi. org/10.1139/b98-170

Frostegård Å, Tunlid A, Bååth E (1991) Microbial biomass measured as total lipid phosphate in soils of different organic content. J Microbiol Methods 14:151-163

Frostegård Å, Tunlid A, Bååth E (2011) Use and misuse of PLFA measurements in soils. Soil Biol Biochem 43:1621-1625. https://doi.org/10.1016/j.soilbio.2010.11.021

García-Cela ME, Marín S, Reyes M, Sanchis V, Ramos AJ (2016) Conidia survival of Aspergillus section Nigri, Flavi and Circumdati under UV-A and UV-B radiation with cycling temperature/light regime. J Sci Food Agric 96:2249-2256. https://doi.org/10.1002/jsfa.7343

Gehrke C, Johanson U, Callaghan TV, Chadwick D, Robinson CH (1995) The impact of enhanced ultraviolet-B radiation on litter quality and decomposition processes in Vaccinium leaves from the subarctic. Oikos 72:213-222. https://doi. org/10.2307/3546223

Gschwind B, Ménard L, Albuisson M, Wald L (2006) Converting a successful research project into a sustainable service: the case of the SoDa web service. Environ Model Softw 21: 1555-1561. https://doi.org/10.1016/j.envsoft.2006.05.002

Gunasekera TS, Paul ND (2007) Ecological impact of solar ultraviolet-B (UV-B: 320-290nm) radiation on Corynebacterium aquaticum and Xanthomonas sp. colonization on tea phyllosphere in relation to blister blight disease incidence in the field. Lett Appl Microbiol 44:513-519. https://doi.org/10.1111/j.1472-765X.2006.02102.x

Hartikainen SM, Jach A, Grané A, Robson TM (2018) Assessing scale-wise similarity of curves with a thick pen: as illustrated through comparisons of spectral irradiance. Ecol Evol 8: 10206-10218. https://doi.org/10.1002/ece3.4496

Hättenschwiler S, Tiunov AV, Scheu S (2005) Biodiversity and litter decomposition in terrestrial ecosystems. Annu Rev Ecol Evol Syst 36:191-218. https://doi.org/10.1146/annurev. ecolsys.36.112904.151932

Johnson D (2003) Response of terrestrial microorganisms to ultraviolet-B radiation in ecosystems. Res Microbiol 154: 315-320. https://doi.org/10.1016/S0923-2508(03)00078-0

Kassambara A (2019) Package 'ggcorrplot' - visualization of a correlation matrix using 'ggplot2'. 0.1.3 edn

King JY, Brandt LA, Adair EC (2012) Shedding light on plant litter decomposition: advances, implications and new directions in understanding the role of photodegradation. Biogeochemistry 111:57-81. https://doi.org/10.1007 /s10533-012-9737-9

Kubartová A, Ranger J, Berthelin J, Beguiristain T (2009) Diversity and decomposing ability of saprophytic Fungi from temperate Forest litter. Microb Ecol 58:98-107. https://doi. org/10.1007/s00248-008-9458-8
Kumagai T (1988) PHOTOCONTROL OF FUNGAL DEVELOPMENT. Photochem Photobiol 47:889-896. https://doi.org/10.1111/j.1751-1097.1988.tb01672.x

Lin Y, Karlen SD, Ralph J, King JY (2018) Short-term facilitation of microbial litter decomposition by ultraviolet radiation. Sci Total Environ 615:838-848. https://doi.org/10.1016/j. scitotenv.2017.09.239

Lin Y, Scarlett RD, King JY (2015) Effects of UV photodegradation on subsequent microbial decomposition of Bromus diandrus litter. Plant Soil 395:263-271. https://doi.org/10.1007/s11104-015-2551-0

Ma Z, Yang W, Wu F, Tan B (2017) Effects of light intensity on litter decomposition in a subtropical region. Ecosphere 8. https://doi.org/10.1002/ecs2.1770

Martinez Arbizu P (2019) pairwiseAdonis: pairwise multilevel comparison using Adonis. R package version 0.3

Møller J, Miller M, Kjøller A (1999) Fungal-bacterial interaction on beech leaves: influence on decomposition and dissolved organic carbon quality. Soil Biol Biochem 31:367-374. https://doi.org/10.1016/S0038-0717(98)00138-2

Moody SA, Newsham KK, Ayres PG, Paul ND (1999) Variation in the responses of litter and phylloplane fungi to UV-B radiation (290-315 nm). Mycol Res 103:1469-1477. https://doi.org/10.1017/S0953756299008783

Moody SA, Paul ND, Björn LO, Callaghan TV, Lee JA, Manetas Y, Rozema J, Gwynn-Jones D, Johanson U, Kyparissis A, Oudejans AMC (2001) The direct effects of UV-B radiation on Betula pubescens litter decomposing at four European field sites. Plant Ecol 154:27-36. https://doi.org/10.1023 /A:1012965610170

Newsham KK, Anderson JM, Sparks TH, Splatt P, Woods C, Mcleod AR (2001) UV-B effect on Quercus robur leaf litter decomposition persists over four years. Glob Chang Biol 7: 479-483. https://doi.org/10.1046/j.1365-2486.2001.00423.x

Newsham KK, Low MNR, McLeod AR, Greenslade PD, Emmett BA (1997) Ultraviolet-B radiation influences the abundance and distribution of phylloplane fungi on pedunculate oak (Quercus rohur). New Phytol 136:287-297. https://doi. org/10.1046/j.1469-8137.1997.00740.x

Oksanen J, Blanchet FG, Kindt R, Legendre P, Minchin PR, O'hara R, Simpson GL, Solymos P, Stevens MHH, Wagner H (2019) Vegan: community ecology package - version 2.5-4

Osman M, Elsayed MA, Mohamed YAH, Abo-Zeid AM (1989) Effect of ultraviolet irradiation on germination and growth in Aspergillus flavus and Penicillium notatum. Mycol Res 92: 293-296. https://doi.org/10.1016/S0953-7562(89)80068-1

Pancotto VA, Sala OE, Cabello M, López NI, Matthew Robson T, Ballaré CL, Caldwell MM, Scopel AL (2003) Solar UV-B decreases decomposition in herbaceous plant litter in Tierra del Fuego, Argentina: potential role of an altered decomposer community. Glob Chang Biol 9:1465-1474. https://doi. org/10.1046/j.1365-2486.2003.00667.x

Pancotto VA, Sala OE, Robson TM, Caldwell MM, Scopel AL (2005) Direct and indirect effects of solar ultraviolet-B radiation on long-term decomposition. Glob Chang Biol 11: 1982-1989. https://doi.org/10.1111/j.1365-2486.2005.1027. $\mathrm{x}$

Paul ND, Gwynn-Jones D (2003) Ecological roles of solar UV radiation: towards an integrated approach. Trends Ecol Evol 18:48-55. https://doi.org/10.1016/S0169-5347(02)00014-9 
Pieristè M, Chauvat M, Kotilainen TK, Jones AG, Aubert M, Robson TM, Forey E (2019a) Solar UV-A radiation and blue light enhance tree leaf litter decomposition in a temperate forest. Oecologia 191:191-203. https://doi.org/10.1007 /s00442-019-04478-x

Pieristè M, Neimane S, Nybakken L, Solanki T, Jones AG, Forey E, Chauvat M, N̦ečajeva J, Robson TM (2019b) Ultraviolet radiation accelerates photodegradation under controlled conditions but slows the decomposition of leaf litter from forest stands in southern Finland. Plant Physiology and Biochemistry Under review

Purahong W, Schloter M, Pecyna MJ, Kapturska D, Däumlich V, Mital S, Buscot F, Hofrichter M, Gutknecht JLM, Krüger D (2014) Uncoupling of microbial community structure and function in decomposing litter across beech forest ecosystems in Central Europe. Sci Rep 4:7014. https://doi. org/10.1038/srep07014 https://www.nature. com/articles/srep07014\#supplementary-information

Rangel DEN, Braga GUL, Flint SD, Anderson AJ, Roberts DW (2004) Variations in UV-B tolerance and germination speed of Metarhizium anisopliae conidia produced on insects and artificial substrates. J Invertebr Pathol 87:77-83. https://doi. org/10.1016/j.jip.2004.06.007

Salamanca EF, Kaneko N, Katagiri S (2003) Rainfall manipulation effects on litter decomposition and the microbial biomass of the forest floor. Appl Soil Ecol 22:271-281. https://doi. org/10.1016/S0929-1393(02)00153-1

Sauvadet M, Fanin N, Chauvat M, Bertrand I (2019) Can the comparison of above- and below-ground litter decomposition improve our understanding of bacterial and fungal successions? Soil Biol Biochem 132:24-27. https://doi.org/10.1016 /j.soilbio.2019.01.022
Song X, Peng C, Jiang H, Zhu Q, Wang W (2013) Direct and indirect effects of UV-B exposure on litter decomposition: a meta-analysis. PLoS One 8:e68858-e68858. https://doi. org/10.1371/journal.pone.0068858

Swift MJ, Heal OW, Anderson JM (1979) Decomposition in terrestrial ecosystems. Univ of California Press, Berkeley \& Los Angeles

Udo S, Aro T (1999) Global PAR related to global solar radiation for Central Nigeria. Agric For Meteorol 97:21-31. https://oi.org/10.1016/S0168-1923(99)00055-6

Velmurugan P, Lee YH, Venil CK, Lakshmanaperumalsamy P, Chae J-C, Oh B-T (2010) Effect of light on growth, intracellular and extracellular pigment production by five pigmentproducing filamentous fungi in synthetic medium. J Biosci Bioeng 109:346-350. https://doi.org/10.1016/j. jbiosc.2009.10.003

Verhoef HA, Verspagen JMH, Zoomer HR (2000) Direct and indirect effects of ultraviolet-B radiation on soil biota, decomposition and nutrient fluxes in dune grassland soil systems. Biol Fertil Soils 31:366-371. https://doi.org/10.1007 /s003749900181

Zhou S, Huang C, Xiang Y, Tie L, Han B, Scheu S (2018) Effects of reduced precipitation on litter decomposition in an evergreen broad-leaved forest in western China. For Ecol Manag 430:219-227. https://doi.org/10.1016/j.foreco.2018.08.022

Publisher's note Springer Nature remains neutral with regard to jurisdictional claims in published maps and institutional affiliations. 